\title{
SEPATU BOOT DAN FETISHISME PADA BIKERS
}

\author{
Anwar Hidayat \\ Staff Pengajar Desain dan Teknologi Produk Kulit, \\ Akademi Teknologi Kulit Yogyakarta \\ E-mail: hanuvar@yahoo.com
}

\begin{abstract}
The rise of motorcycles in Indonesia, triggered the emergence of motor communities. The existence of these communities cannot be separated from the attributes worn like a vest, gloves, and boots. This study aims to find out why a lot of boots worn by the biker community. The method used in this research were qualitatif which Kawasaki Ninja Community in Yogyakarta as case study approach. Fetishism theory used, based on the theories of Karl Marx and Jean Baudrillard, which were to review the theory of commodity fetishism in which revealing about the use value, exchange value, symbolic value and sign value on the boots. The result shows use value of boots in this community was that these shoes protected feet of the risk of collision, sprains, and protected feet from hot engine. In addition,it is to facilitate the rider in performing activities gearshift. Exchange value of boots was that synthetic materials were commonly used by the community since leather boots more expensive than synthetic materials. Symbolic values that arises is the existence of a social status that distinguishes between the large capacity of Kawasaki Ninja (250 cc and above) with the others, which confirms the existence of their boots were more exclusive. Sign value that appear was the need to identity that distinguishes the model selection type of sports shoes which deliver the message as well as the motorsport rider.
\end{abstract}

Keywords: motorcycle community, boots, fetishism. 
Vol. 1, No. 2, April 2014

\section{INTISARI}

Maraknya jumlah sepeda motor di Indonesia, turut memicu munculnya komunitas-komunitas motor. Keberadaan komunitas tersebut tidak terlepas dari atribut yang dikenakan seperti rompi, sarung tangan, dan terutama sepatu boot. Kajian ini bertujuan untuk mencari tahu mengapa sepatu boot banyak dipakai oleh komunitas bikers tersebut. Metode yang digunakan dalam penelitian ini adalah kualitatif dengan pendekatan studi kasus pada Komunitas Kawasaki Ninja di Yogyakarta. Teori Fetishism yang digunakan, mengacu pada teori dari Karl Marx dan Jean Baudrillard, dimana teori tersebut mengulas pada fetisisme komoditas yang didalamnya mengungkap tentang nilai guna, nilai tukar, nilai simbolik dan nilai tanda pada sepatu boot yang dikenakan. Hasil kajian ini menunjukkan bahwa nilai guna sepatu boot pada komunitas ini adalah sepatu tersebut melindungi kaki dari resiko benturan, terkilir, dan melindungi kaki dari panas mesin. Selain itu juga untuk mempermudah pengendara dalam melakukan aktifitas perpindahan gigi. Nilai tukar dari sepatu boot yang digunakan adalah bahwa komunitas ini banyak menggunakan sepatu motorcycle boot yang menggunakan bahan sintetis karena sepatu boot berbahan kulit lebih mahal harganya. Nilai simbolik yang muncul adalah adanya status sosial yang membedakan antara motor Kawasaki Ninja yang berkapasitas besar (250 cc ke atas) dengan motor lainnya, dimana sepatu boot menegaskan keberadaan mereka secara lebih eksklusif. Nilai tanda yang muncul yaitu adanya kebutuhan identitas yang membedakan dengan pemilihan model sepatu bertipe sport yang memberikan pesan kecepatan seperti halnya pembalap motorsport.

Kata Kunci : komunitas motor, sepatu boot, fetishism.

\section{PENDAHULUAN}

Seiring dengan pertumbuhan ekonomi masyarakat Indonesia, tingkat kebutuhan alat transportasi untuk menunjang mobilitas semakin meningkat. Dari tahun ke tahun tren melonjaknya penjualan motor semakin tinggi, seperti terlihat dari data Asosiasi Industri Sepeda Motor Indonesia bahwa pada Tahun 2009 penjualan motor sebesar 5,851,962, Tahun 2010 sebesar 7,369,249, Tahun 2011 sebesar 8,012,540, dan Tahun 2012 sebesar 7,064,457 unit (www.aisi.or.id).
Keberadaan motor tersebut secara tidak langsung juga berkaitan dengan munculnya komunitas-komunitas bikers yang belakangan ini marak di Indonesia. Komunitas Bikers banyak muncul di perkotaan Indonesia dengan masih terikat dengan produsen pemilik merek. Berbagai nama komunitas seperti Harley Davidson Club Indonesia (HDCI), Komunitas Tigers Indonesia, Kawasaki Ninja Indonesia Community, maupun yang menggemari motor-motor bebek seperti Mio, Vario, dan merek-merek lainnya. Selain itu, juga ada 
Anwar Hidayat, Desain Sepatu Boot Fetishisme Pada Bikers

komunitas-komunitas yang setia dengan motor tua maupun motor besar seperti Motor Antique Club Yogyakarta (MACY) dan IMBI (Ikatan Motor Besar Indonesia).

Menjadi menarik untuk diamati adalah bahwa keberadaan komunitaskomunitas tersebut tidak bisa lepas dengan berbagai atribut yang dikenakannya. Atribut pelengkap berkendara seperti sepatu, sarung tangan, dan jaket maupun rompi yang dikenakan rata-rata adalah dari bahan kulit. Seperti diketahui bahwa material kulit merupakan material eksklusif yang kuat dan tahan cuaca. Atribut-atribut tersebut bahkan menjadi syarat safety riding saat komunitas tersebut mengadakan kegiatan touring ke daerah-daerah lain. Khusus pada atribut sepatu yang digunakan oleh kalangan bikers tersebut, banyak yang menggunakan sepatu boot dalam berkendara terutama pada komunitas motor besar, motor sport dan motor klasik. Tetapi kalangan bikers bermotor bebek pun saat ini juga marak memakai sepatu boot.

Sepatu menjadi menjadi penting dalam safety riding karena fungsinya adalah untuk melindungi kaki jika terjadi benturan dan melindungi kaki dari cuaca ekstrim. Penggunaan sepatu dalam safety riding selain itu juga untuk memudahkan dalam pengendalian berkendara saat menginjak rem maupun saat melakukan perpindahan gigi secara cepat dengan mengandalkan cengkeraman sol yang kuat dengan menggunakan bahan karet.

Fenomena yang menarik dalam hal ini adalah bahwa penggunaan sepatu boot tersebut banyak dipakai oleh bikers dari berbagai kalangan baik yang motor besar maupun yang menggunakan motor bebek.
Seperti diketahui bahwa di Indonesia ini memiliki iklim tropis dan panas, sedangkan dengan memakai sepatu boot tersebut akan terasa panas pada bagian kaki, dimana secara ergonomi posisi saraf banyak terdapat pada telapak kaki. Menjadi pertanyaan tersendiri yang menjadi masalah untuk dikaji terkait dengan permasalahan sepatu boot yang digunakan para bikers, yaitu mengapa sepatu boot tersebut digemari oleh komunitas bikers? Apa makna yang ingin ditunjukkan dengan pemakaian sepatu boot tersebut?

Sementara itu, dilihat dari runutan sejarahnya seperti yang dijelaskan oleh Valerie Steel dalam buku Shoes: A Lexicon of Style (1998), sepatu boot dikenal erat hubungannya dengan kegiatan mengendarai kuda, dihubungkan bahwa hal tersebut terkait baik dalam kegiatan militer, dimana pengendara kuda (cavalry) menduduki status lebih tinggi sebagai pasukan elit. Selain itu juga dalam perkembangannya di dunia Barat, dimana sepatu boot mulai digunakan oleh koboi (cowboy) dalam mengawal ternakternaknya di padang Amerika. Kemudian, sepatu boot mulai terus dimunculkan oleh para artis, tokoh masyarakat dan pengendara Harley Davidson dalam kegiatan sehari-hari.

\section{METODE}

Metode penelitian yang digunakan dalam kajian sepatu boot ini adalah kualitatif dengan pendekatan studi kasus pada kalangan bikers di Yogyakarta. Pendekatan studi kasus dilakukan dengan mengeksplorasi permasalahan sepatu boot yang digunakan oleh kalangan bikers. Data yang digunakan dalam kajian ini adalah data kepustakaan yang diambil dari sumber- 
Vol. 1, No. 2, April 2014

sumber literatur dan internet, yang kemudian dianalisa kedalamannya dengan melakukan observasi dan wawancara.

\section{Pendekatan Teori}

Dalam mengkaji penggunaan sepatu boot oleh kalangan bikers tersebut, maka disini digunakan pendekatan teori yaitu Fetishism (fetisisme). Fetisisme sering hanya diketahui sebagai sebuah kecenderungan obsesi berlebihan yang dikaitkan dengan disorientasi sexual jika mengacu pada keberadaan kaum gay dan kecenderungan sado masokis (Sadomasochist/S \& M). Walaupun Fetisisme sendiri pada perkembangannya juga berkaitan dengan sexual fetishism dan foot fetishism. Fetishism disini adalah tentang objek yang dipercaya memiliki kandungan kekuatan supernatural atau unatural. Fetish berasal dari bahasa Perancis; fetice, yang juga merupakan serapan dari bahasa Portugis; feitico, yang berarti artifisial atau buatan (http:// en.wikipedia.org/wiki/Fetishism).

Teori tentang Fetisisme yang lain disampaikan oleh Karl Marx yaitu teori fetisisme komoditas (commodity fetishism) yang ada pada bukunya Kapital I: Proses Produksi Kapital (2004). Dalam bab pertama buku tersebut Karl Marx menjelaskan tentang ekonomi politik kapitalisme, komoditas fetisisme dijelaskan sebagai persepsi hubungan sosial yang terkait dengan aspek produksi, bukan sebagai hubungan antar orang, tetapi sebagai hubungan ekonomi antara uang dan komoditas yang dipertukarkan dalam sistem perdagangan. Dengan demikian fetisisme komoditas mengubah aspek nilai abstrak ekonomi menjadi sesuatu yang obyektif, kenyataan yang dianut oleh masyarakat dimana dalam benda terkandung nilai-nilai intrinsik. Karl Marx juga menekankan bahwa ketika orang memproduksi barang untuk dipasarkan, nilai dari barang tersebut tidak tergantung dari tingkat kegunaan, tetapi pada kemampuannya untuk membuat perubahan.

Karl Marx membongkar sesuatu yang selama ini 'sakral' ditabrak, yaitu pemikiran Marx yang kini membongkar mitos-mitos dalam berbagai profesi. Para dokter, ahli hukum, penulis puisi, ilmuwan sekarang dilukiskan sebagai tidak lebih dari buruh yang dibayar. Ternyata ketika satu bentuk mistifikasi tadi terbongkar oleh ekspansi bisnis, fetisisme barupun menggantikannya yaitu fetisisme komoditas (Sutomo, 2003: 32).

Karl Marx menjelaskan bahwa komoditas hanya memiliki dua aspek, yaitu: use value dan exchange value. Benda yang memiliki use value berguna dalam logika praktik, nilai guna apa yang terdapat dalam benda tersebut, tidak mungkin jika sebuah benda tidak memiliki use value. Sementara itu, dalam exchange value menekankan pada logika kesetaraan yang sejalan dengan nilai tukar, sebagai contoh segelas air di gurun pasir mungkin saja bernilai sama dengan seekor keledai. Oleh karena itu, Marx menekankan pentingnya produksi dalam ekonomi (Marx, 2004: 6).

Marx berpikir bahwa komoditas memiliki kesamaan, yang memungkinkan mereka untuk secara sistematis mencapai nilai, adalah bahwa mereka mengekspresikan tenaga kerja dari para pekerja. Nilai tukar akhirnya mengikuti dari jumlah dan jenis tenaga kerja yang didefinisikan secara sosial yang masuk dalam komoditas (Robinson, 2009: 2). 
Baudrillard dalam buku Masyarakat Konsumsi (2004) menjelaskan tentang fetisisme sebagai sesuatu yang bekerja dalam lalu lintas penandaan sosial. Baudrillard melengkapi konsep fetisisme komoditas Marx dengan meneliti fetisisme nilai guna dan dampak sosial pada aktivitas konsumsi. Baudrillard juga mengembangkan pemahaman Freud mengenai nilai godaan (seksual) yang terdapat pada obyek untuk memahami hasrat subyek terhadap obyekoyek dalam sirkulasi tanda yang kemudian membentuk keluasan aktivitas konsumsi. Baudrillard sebagai salah satu tokoh yang dianggap memperkenalkan semangat postmodern dalam melihat permasalahan fetisisisme dan apa saja yang berkaitan dengannya dari sudut pandang yang berbeda dari dua pemikir diatas.

Dalam Masyarakat Konsumsi (2004), Baudrillard menjelaskan bahwa sebuah benda tidak hanya memiliki use value dan exchange value, tetapi juga memiliki symbolic value dan sign value. Symbolic value adalah logika mendua yang sejalan dengan nilai simbolik, berhubungan dengan hubungan subjek dengan subjek lain. Sedangkan sign value adalah logika perbedaan yang sejalan dengan nilai tanda, yang menempatkan objek lain yang berhubungan dengan tanda lainnya, contohnya seperti pada fashion. Baudrillard berpendapat bahwa konsumsilah yang menjadi inti ekonomi, bukan produksi. Konsumsi membuat manusia tidak mencari kebahagiaan, tidak berusaha mendapatkan persamaan, dan tidak adanya intensitas untuk melakukan homogenisasi - manusia justru melakukan diferensiasi (perbedaan) yang menjadi acuan dalam gaya hidup dan nilai, bukan kebutuhan ekonomi. Hal inilah yang terjadi pada fashion, keinginan untuk menjadi berbeda memicu terjadinya kegiatan ekonomi yang berbasis pada konsumsi 'sign value', manusia lebih memilih untuk mengonsumsi tanda daripada melihat kegunaan objek itu sendiri. Masyarakat seperti ini disebut Baudrillard sebagai masyarakat konsumer.

Ciri masyarakat konsumer adalah ketika objek menandai status sosial hingga menggantikan kedudukan sosial yang berdasar pada ras, gender, dan kelas. Seseorang mendapatkan prestise dari konsumsi tanda yang dia lakukan terlepas dari ras, gender, dan kelasnya. Konsumsi dapat memanipulasi tanda yang menandakan status sosial melalui perbedaan-perbedaan tersebut. Konsumsi adalah ujung di mana komoditas diproduksi sebagai suatu tanda, dan tanda-tanda itu (yang mengindikasikan adanya kebudayaan) diproduksi sebagai komoditas. Konsumsi tidak sama dengan kegiatan membeli, karena kegiatan membeli didasarkan pada use value, sedangkan konsumsi didasarkan pada sign value (http:/ /ismoyojessy.blogspot.com/2011/11/ masyarakat-konsumer-menurutbaudrillard.htm).

\section{Data}

Bikers yang ada di Yogyakarta saat ini lebih banyak didominasi oleh para pengguna motor buatan Jepang jika dibandingkan dengan motor-motor besar buatan negara-negara Eropa maupun Amerika. Hal tersebut terjadi lebih dikarenakan banyaknya varian motor Jepang yang relatif lebih terjangkau harganya sehingga peredarannya otomatis lebih banyak. Kemudahan dalam hal kepemilikan juga menjadi faktor penentu banyaknya motor buatan Jepang yang beredar, 
mengingat sistem perkreditan dan leasing yang menjamur di kota Yogyakarta. Keberadaan motor-motor buatan Eropa dan Amerika di Yogyakarta terbatas pada kalangan tertentu saja, yaitu hanya dimiliki oleh kalangan menengah ke atas yang notabene lebih kuat dalam hal finansialnya seperti Harley Davidson Club Indonesia (HDCI). Di antara komunitas bikers di Yogyakarta tersebut komunitas bikers Kawasaki Ninja Yogyakarta termasuk salah satu komunitas yang banyak mempergunakan atribut safety riding secara lengkap, terutama saat melakukan touring.

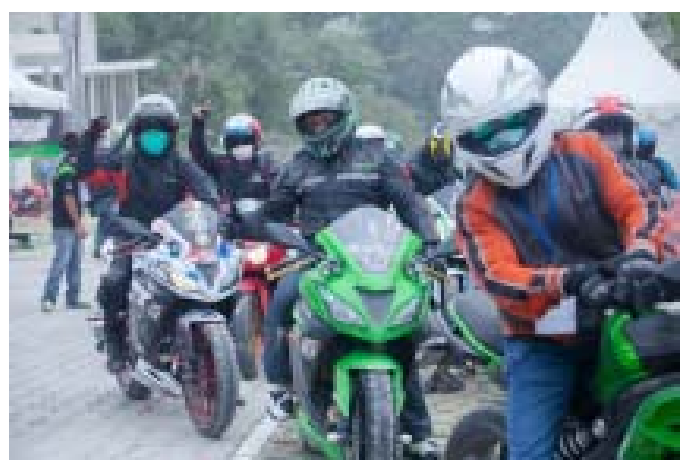

Gambar 1. Kegiatan touring Bikers Kawasaki Ninja

Khusus komunitas bikers Kawasaki Ninja tersebut ada beberapa wadah, seperti Merapi Ninja 250 Community (MNTC), dan ada juga Jogja Punya Ninja (JPN) yang berafiliasi dengan Kawasaki Ninja Indonesia (KNI) yang merupakan klub motor berskala nasional. Perbedaan antar komunitas tersebut adalah pada spesifikasi motor yang menjadi syarat keanggotaan, jika pada JPN syarat keanggotaan adalah para pengguna sepeda Kawasaki Ninja berkapasitas 125 cc, 150 cc, dan 250 cc, maka MNTC mengkhususkan diri pada motor Kawasaki Ninja 250 cc atau motor sejenis yang mempunyai kapasitas lebih besar.

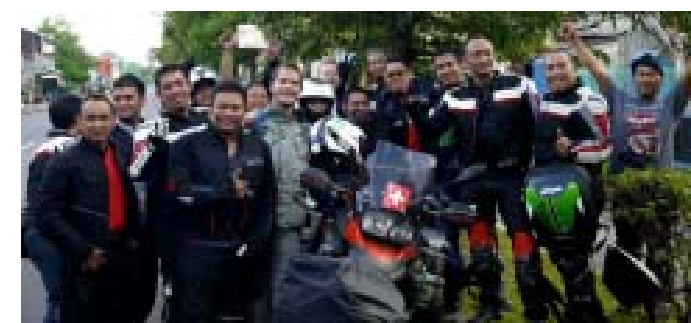

Gambar 2. Komunitas Bikers Merapi Ninja 250 Community

Penggunaan atribut saftey riding bagi komunitas ini sangat penting seperti yang diungkapkan oleh Wawan Budi (pegiat komunitas motor Kawasaki Ninja Indonesia di Yogyakarta). Atribut standar yang digunakan adalah pelindung kepala/helm, jaket, sarung tangan, dan sepatu. Kebutuhan akan atribut tersebut disesuaikan dengan kebutuhan tiap pengendara, terutama terkait dengan bahan yang digunakan. Bahan dari material kulit secara otomatis akan lebih mahal jika dibandingkan dengan material sintetis, terutama pada sepatu.

Menurut Wawan, penggunaan sepatu oleh kalangan bikers adalah sebuah keharusan karena sepatu akan memberikan rasa aman bagi pengendaranya. Pemakaian sepatu juga untuk menghindari resiko apabila terjadi benturan/kecelakaan. Perbedaan antara penggunaan sepatu potongan rendah dan potongan tinggi (boot) adalah fungsi perlindungan kaki pada resiko terkilir dan perlindungan kaki dari panas mesin, sehingga sepatu boot lebih banyak digunakan oleh pengendara motor laki-laki (non bebek). Posisi mesin motor berkapasitas besar pada motor laki biasanya berada di bawah tangki bensin, sehingga posisi tersebut berada sejajar dengan posisi kaki saat dikendarai, hal tersebut akan menimbulkan rasa panas di kaki terutama pada motor berkapasitas besar (di atas $250 \mathrm{cc}$ ). 
Anwar Hidayat, Desain Sepatu Boot Fetishisme Pada Bikers

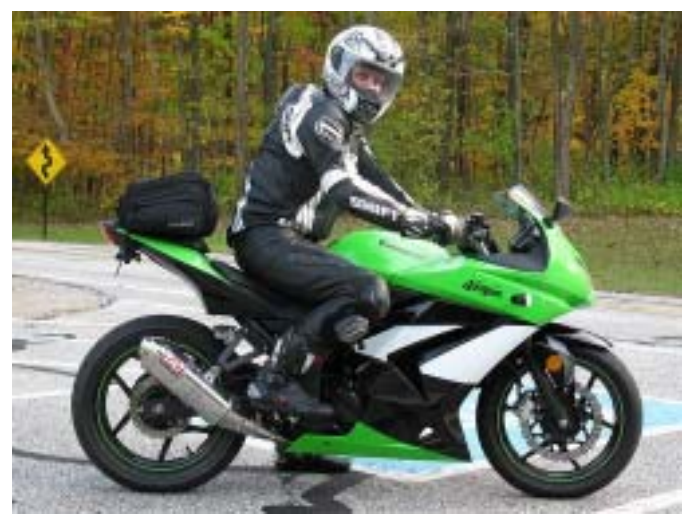

Gambar 3. Atribut lengkap yang digunakan rider Kawasaki Ninja Indonesia

Selain aspek fungsional, sepatu boot dan atribut jaket juga menjadi identitas bikers, yaitu sebagai penanda antara komunitas yang satu dengan yang lainnya. Sepatu boot yang digunakan bikers banyak ragamnya, baik itu yang menggunakan bahan kulit maupun yang bahan sintetis. Pilihan material tersebut disesuaikan dengan budget yang dimiliki oleh masing-masing pengendara, karena harganya relatif mahal. Bikers Kawasaki Ninja 250 cc di Yogyakarta mengakui bahwa sepatu boot yang berbahan kulit lebih bagus dalam perlindungan kaki tetapi tidak semua bikers memilikinya, sehingga pilihan sepatu boot lebih banyak pada sepatu berbahan sintetis dan bahkan sepatu dengan model potongan rendah tetapi dengan tambahan pelindung kaki, karena sudah memenuhi standar keamanan touring dan lebih sporty. Mereka merasa dengan memakai sepatu boot tersebut dan jaket komunitas, akan ada rasa aman dan rasa percaya diri saat melakukan tour ke luar daerah. Model sporty banyak menjadi pilihan karena seperti citra pembalap yang cepat dan praktis.

\section{PEMBAHASAN}

Keberadaan sepatu boot yang mengiringi komunitas motor Kawasaki Ninja di Indonesia tidak terlepas dari aspek-aspek kegunaan/fungsi, aspek harga, dan aspek simbol identitas yang ditampilkan. Di kehidupan modern saat ini, sepatu sudah menjadi elemen penting dalam fesyen, yaitu menjadi pelengkap busana yang memiliki peran praktis dan estetis. Dalam berbagai aktifitas, orang akan menyesuaikan busana yang dikenakan dengan sepatu yang digunakan sesuai dengan kegiatan atau profesi yang digeluti.

Secara historis sepatu dibuat dengan tujuan utama adalah untuk melindungi kaki, baik itu dari cuaca, gigitan binatang, dan benturan dengan obyek disekitarnya. Menurut Demello (2009) dalam buku Feet and Footwear, para ilmuwan berteori bahwa sebenarnya sepatu ataupun sandal sudah dikenal sejak ribuan tahun yang lalu oleh Homo sapiens di Eurasia, sepatu kulit binatang sudah digunakan untuk melindungi kaki dari dingin dan salju sejak 50.000 tahun yang lalu di daerah kutub utara. Dahulu sepatu hanya digunakan sebagai lapisan pelindung kaki, tetapi saat ini fungsi sepatu menjadi lebih canggih dan menjadi penanda status sosial dalam masyarakat. Perubahan fungsi sepatu secara bertahap mengalami pergeseran dari masa ke masa. Perkembangan peradaban manusia yang ditandai dengan budaya, seni, maupun perkembangan teknologi, meninggalkan jejak yang jelas pada produk sepatu ini. Hal tersebut dapat dilihat dari trend mode yang berlaku dari tahun ke tahun sejak sepatu mulai dikenal oleh manusia.

Menurut Steel (1998) dalam buku Shoes: A Lexicon of Style, sepatu sudah dikenal oleh bangsa Indian dengan cara membungkus kaki menggunakan kulit binatang. Munculnya sepatu boot di Amerika ditandai sejak kedatangan bangsa Inggris datang ke Amerika, sehingga mulailah muncul sepatu boot yang banyak digunakan oleh Cowboy seperti yang kita kenal sampai saat ini. Sepatu boot lebih banyak dikenal di 


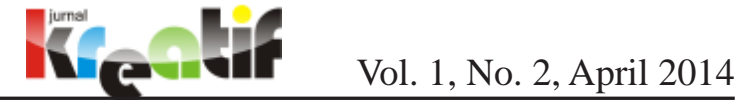

dunia barat dimana cuaca dingin lebih dominan, pada suhu tersebut sepatu dengan model potongan tinggi seperti sepatu boot dapat melindungi sampai bagian betis. Sepatu jenis ini juga digunakan oleh para tentara dimana para tentara tersebut diharuskan melalui medan yang sulit dan melawan cuaca ekstrim.

\section{Nilai guna (use value)}

Merujuk pada pendapat Marx (2004), bahwa suatu komoditi harus memiliki use value dan exchange value. Use value atau nilai guna disini dipahami sebagai keterkaitan antara pemenuhan suatu kebutuhan akan komoditas dengan aspek fungsi secara praktis akan kegunaan komoditas tersebut, sehingga akan memunculkan dan mendongkrak nilai tersebut. Aspek kegunaan secara historis pada sepatu boot pada awalnya memang dikhususkan untuk para pengendara kuda, hal tersebut ditunjukkan dengan model yang tinggi untuk melindungi kaki dari cuaca ekstrim yang dingin dan rentan hujan di daratan Eropa maupun Amerika, potongan yang tinggi dari sepatu boot adalah untuk melindungi kaki. Elemen dasar sepatu boot koboi memang dirancang untuk pengendara kuda, kekhasannya adalah pada bagian ujung depan kaki jari kaki yang bulat atau meruncing, sebenarnya adalah untuk memudahkan memasukkan kaki ke dalam behel pijakan dan dibuat licin untuk memungkinkan boot cepat lepas ketika turun dari kuda. Adanya bagian gir (gear) yang terpasang pada bagian tumit, difungsikan untuk menghela kuda supaya mengikuti perintah pengendara dengan cara menendangkannya pada bagian perut kuda. Bagian hak (heel) sepatu boot yang tinggi difungsikan untuk mencengkeram behel pijakan alas kaki supaya bisa stabil saat berkendara.

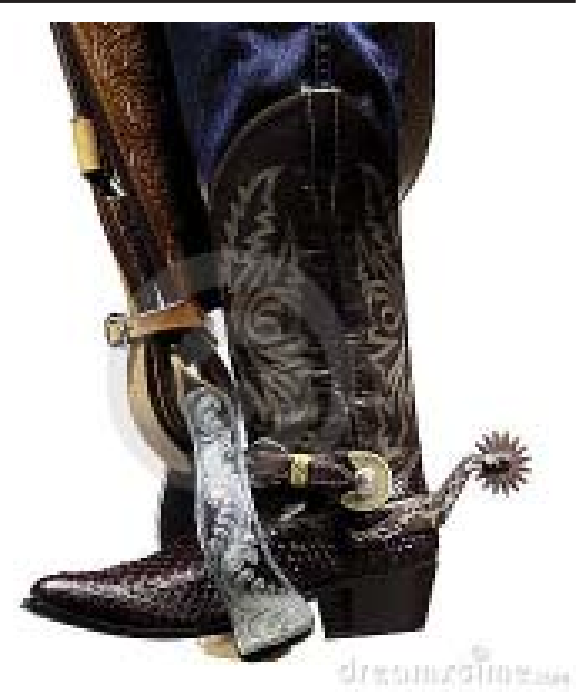

Gambar 4. Model sepatu koboi klasik

(sumber : http://dreamstime.com)

Penggunaan sepatu boot oleh kalangan bikers motor Kawasaki Ninja di Yogyakarta seperti diungkapkan oleh Wawan lebih banyak menitikberatkan pada aspek kegunaan dari sepatu, yaitu sebagai pelindung kaki dan sarana untuk memudahkan aktifitas berkendara. Berpijak pada pendapat Marx (2004) tentang use value (nilai guna), komoditi sepatu boot tersebut secara kegunaan adalah untuk melindungi kaki dari panasnya mesin motor dan resiko benturan pada benda keras akibat terjatuh/ kecelakaan. Para bikers Kawasaki Ninja 250 cc di Yogyakarta tersebut memahami aplikasi sepatu boot sebagai item wajib berkendara, karena panas yang dihasilkan mesin motor sangat terasa di kaki apabila digunakan untuk touring. Walaupun motor Ninja yang digunakan secara desain standar yang dikeluarkan oleh pabrikan sudah menggunakan fairing (penutup di samping mesin), tetapi tetap masih panas karena fungsi utama fairing tersebut adalah untuk tujuan aerodinamika, bukanlah sekedar untuk penutup semata. Justru saat berkendara dengan kecepatan sedang, angin yang dipecah oleh fairing tersebut mengalir melewati kaki pengendara, hal tersebutlah yang membuat sepatu boot menjadi penting. 
Anwar Hidayat, Desain Sepatu Boot Fetishisme Pada Bikers

Use value dari material kulit yang digunakan adalah karena material kulit memiliki kemampuan meredam panas yang baik, tetapi saat ini material sintetis juga sudah memiliki kemampuan yang baik untuk menahan panas. Berbagai terobosan teknologi material saat ini membuat kulit imitasi dapat mensubstitusi kulit asli, sehingga kebutuhan akan kelenturan dan kenyamanan saat digunakan bisa didapat dengan material ini.

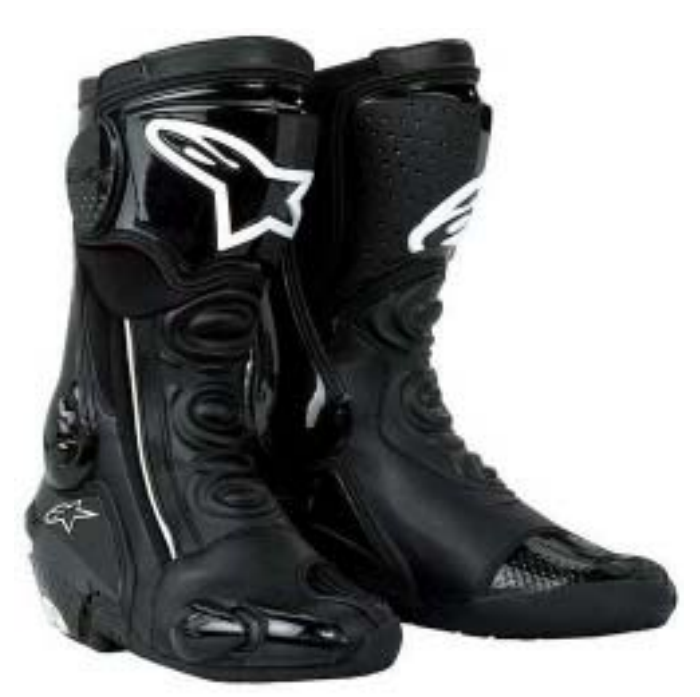

Gambar 5. Sepatu riding berbahan sintetis

Hak tinggi (high heel) pada sepatu boot kurang cocok pada pengendara motor Kawasaki Ninja mengingat bentuk pijakan motor yang memiliki diameter lebar dan diselubungi dengan karet untuk mencengkeram. Sehingga sepatu rider yang lebih nyaman adalah justru model sol yang flat (tanpa heel). Model potongan tinggi selain perlindungan panas juga untuk perlindungan pada mata kaki, yaitu saat mengalami kecelakaan dan terjadi kaki terpelintir maka ada sarana yang menahan patahnya pada bagian mata kaki. Trasformasi sepatu cowboy boot ke sepatu motorsycle boot tersebut lebih pada perubahan fungsi berkendara. Berbagai bentuk yang muncul pada sepatu boot motor tersebut mengikuti fungsi operasional penggunaan motor. Para pengguna Kawasaki Ninja memakai sepatu boot motor karena ada fungsi pengungkit pada ujung depan sepatu (pada lapisan atas ibu jari kaki kiri), karena lebih memudahkan perpindahan gigi persneling Kawasaki Ninja. Motor Kawasaki Ninja memiliki sistem perpindahan gigi dengan cara diungkit bukan dipijak, mengikuti model motor balap. Hal tersebut bertujuan untuk mempercepat proses pemindahan gigi dan mengefektifkan pergerakan kaki.

\section{Nilai tukar (exchange value)}

Komunitas bikers Kawasaki Ninja di Yogyakarta lebih memilih sepatu boot berbahan sintetis dibanding sepatu boot berbahan kulit asli, dengan alasan bahwa harga sepatu boot kulit jauh lebih mahal, walaupun mereka mengakui bahwa sepatu boot dari kulit lebih menjamin akan keamanan dan kenyamanan. Pendapat Marx tentang exchange value membuktikan bahwa mahalnya produk berbahan kulit asli meningkat jauh lebih tinggi karena adanya perubahan nilai. Aspek kesadaran manusia akan perlindungan binatang, terutama dipicu oleh punahnya banyak binatang langka karena diburu kulitnya untuk dijadikan material eksotis. Kelompok pecinta lingkungan marak mengkampanyekan akan perlunya perlindungan dan menentang berbagai bentuk eksploitasi bagian tubuh binatang yang menjadi hiasan semata. Faktor-faktor tersebut membuat produk berbahan kulit asli menjadi eksklusif dan meningkat nilai jualnya, semakin langka maka semakin mahal harganya.

Di Indonesia, produk yang berbahan kulit asli menjadi mahal karena juga dipicu oleh berbagai faktor seperti kebijakankebijakan pemerintah yang kurang sesuai. Beberapa tahun terakhir industri kulit Indonesia mengkritik kebijakan pemerintah yang memudahkan akses ekspor kulit yang belum di finishing, sehingga kulit tersebut banyak yang di ekspor keluar dari Indonesia karena harga yang lebih menjanjikan. Dampak bagi industri sepatu (termasuk juga 
Vol. 1, No. 2, April 2014

sepatu boot) adalah terjadinya kelangkaan material kulit berkualitas di dalam negeri. Sementara itu disisi lain, saat dibuka keran impor material kulit, yang terjadi adalah pembatasan akses impor karena isu PMK (Penyakit Mulut dan Kuku) pada sapi yang berimbas pada langkanya daging sapi dan juga kulit sapi. Kelangkaan material tersebut pada akhirnya menjarah ke wilayah industri pembuatan produk jadi yang dalam hal ini adalah industri sepatu (boot). Sepatu boot berbahan sintetis saat ini di Yogyakarta juga relatif mahal, karena sepatu riding yang berkualitas bagus rata-rata harus impor dari luar negeri. Harga yang dari negara asalnya relatif terjangkau, saat masuk ke Indonesia sudah mengalami perubahan nilai tukar karena berbagai faktor seperti shipping, transportasi, dan pengenaan pajak. Dampak dari berbagai hal tersebut menjadikan nilai tukar (exchange value) komoditi sepatu boot di Yogyakarta menjadi tinggi.

\section{Nilai simbolis (symbolic value) dan nilai tanda (sign value)}

Berdasar pada temuan lapangan bahwa pengendara Kawasaki Ninja di Yogyakarta menggunakan sepatu boot saat berkendara, selain faktor-faktor nilai guna ternyata juga karena adanya pemenuhan rasa aman dan percaya diri. Kebutuhan akan identitas kelompok ditampilkan dari atribut jaket, sarung tangan dan sepatu motorcycle boot yang bercitra sporty. Saat mereka menggunakan semua itu secara lengkap, maka sensasi perasaan akan keyakinan diri mereka dalam melintasi berbagai medan akan bangkit. Pada berbagai kegiatan touring yang dilakukan, atribut tersebut menegaskan akan citra pemotor sport seperti halnya pembalap Moto GP yang sedang menjadi trend seiring seringnya siaran TV balap motor ditayangkan di stasiun televisi swasta Indonesia.

Fenomena pemakaian sepatu boot tersebut di kalangan anak motor di Indonesia khususnya pada kasus bikers Kawasaki Ninja di Yogyakarta dapat didefinisikan pada adanya fetishism, yang menurut wikipedia didefinisikan sebagai kepercayaan pada objek yang diyakini memiliki kandungan kekuatan supernatural atau unnatural. Adanya suatu keyakinan yang memberikan sugesti bahwa dengan memakai sepatu boot tersebut mereka bukan hanya merasa aman, tetapi juga faktor kepercayaan diri yang tinggi terutama saat bertemu dengan pengendara-pengendara yang lain.

Keberadaan status dan strata sosial tidak hanya ada dalam kehidupan masyarakat dalam kehidupan sehari-hari, pada komunitas-komunitas bikers juga muncul strata tersebut. Status sosial yang muncul bermula dari jenis motor yang dimiliki atau dikendarai, strata tersebut bisa diklasifikasikan pada kapasitas motor dan harga motor tersebut. Motor-motor yang memiliki kapasitas besar seperti Harley Davidson, BMW, dan berbagai jenis motor keluaran Eropa membentuk kelompok eksklusif sendiri. Sepeda motor keluaran Jepang pun mulai terklasifikasi antar merk dagang dan kapasitas (cc) yang terpasang, seperti halnya Kawasaki Ninja Indonesia yang hanya membuka diri pada pemilik Kawasaki Ninja walaupun pabrikan Kawasaki sendiri memiliki berbagai varian model. Pada Kawasaki Ninja juga, kelompok yang lebih elit muncul yaitu kelompok MNTC yang mengkhususkan diri pada Kawasaki Ninja 250 cc ke atas, hal tersebut terlihat jelas dari kepanjangan MNTC yaitu Merapi Ninja 250 Up Community. 


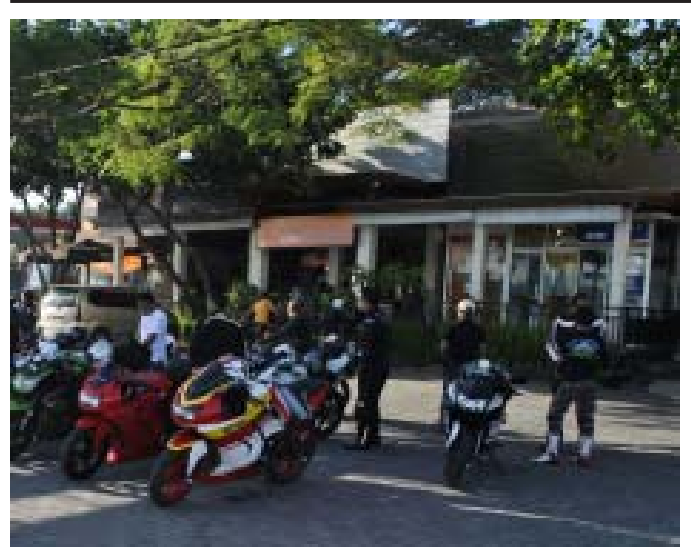

Gambar 6. Sepatu boot yang dikenakan MNTC

Merujuk pada pendapat Baudrillard (2004) bahwa sebuah benda tidak hanya memiliki use value dan exchange value seperti yang diungkapkan Marx, tetapi sebuah benda juga memiliki symbolic value dan sign value. Symbolic value atau nilai simbolis dan sign value dari benda yang kenakan bukan lagi berbicara antara objek dengan subjek, tetapi lebih ditekankan pada hubungan subjek satu dengan subjek yang lainnya yang didalamnya terdapat relasirelasi makna yang mau disampaikan. Menggunakan pendekatan teori tersebut, maka penggunaan sepatu boot dalam perkembangannya memang juga mengalami perluasan, tidak hanya dilihat dari segi utilitas use value dan exchange value semata, tetapi sudah merambah ke wilayah pemaknaan.

Strata sosial juga memisahkan antara kelompok motor besar yang bercitra sport dan adventure, dengan motor-motor bebek yang lebih banyak beredar di pasaran Indonesia. Kelompok motor bebek ini mulai marak akhir-akhir ini di berbagai kota di Indonesia dan keberadaan mereka juga memiliki aktifitas yang sama dengan kelompok motor besar seperti halnya touring, kumpul bareng, dan bakti sosial ke daerah-daerah. Tiap-tiap kelompok tersebut kemudian mulai memasang atribut-atribut yang menjadi penanda kelompoknya, seperti terlihat dari jaket ataupun sepatu yang dikenakan. Atribut tersebut selain sebagai sarana pendukung keamanan berkendara tetapi juga menegaskan eksistensi akan kelompoknya, sehingga muncullah beragam bentuk identitas kelompok.

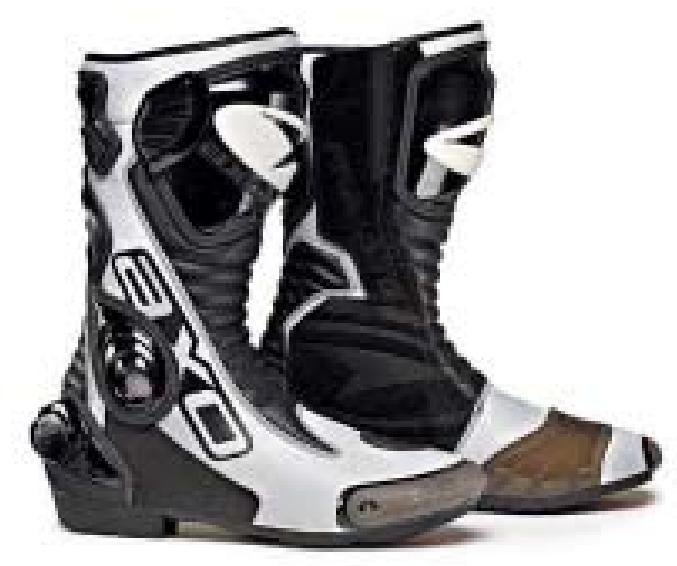

Gambar 7. Sepatu motorcycle boot bergaya sporty

Kelompok Kawasaki Ninja di Yogyakarta juga memiliki atribut serupa, pilihan mereka adalah pada jenis atribut bercitra sporty yaitu pembalap dengan model jaket yang aerodinamis dan sepatu boot seperti halnya pembalap motor sport. Kebutuhan akan atribut dengan identitas kelompok tersebut merupakan bagian dari simbol dan penanda seperti teori yang dikemukakan oleh Baudrillard di atas. Pemakaian sepatu boot tidak lagi dilihat sebagai kebutuhan akan subyek (user/ pengguna) pada obyek (sepatu boot) yang dikenakan yaitu pelindung kaki, melainkan sudah berbicara antara subyek sebagai bikers dengan subyek-subyek lainnya dengan menyampaikannya melalui berbagai atribut yang dikenakan terutama sepatu boot. Sepatu boot model sport yang digunakan oleh komunitas bikers Kawasaki Ninja di Yogyakarta mewakili pemaknaan simbolis akan status sosial yang lebih tinggi jika dibanding para pengguna motor bebek atau motor buatan Jepang lainnya. 
Vol. 1, No. 2, April 2014

Steele (1998) menyatakan bahwa dalam masyarakat feodal Eropa di awal masa modern, seseorang yang mengendarai kuda rata-rata adalah aristokrat atau ksatria cavalry yang menggunakan sepatu boot, sehingga sepatu boot juga melambangkan kekuatan dan status sosial yang tinggi. Sepatu boot sebelumnya dikenal erat hubungannya dengan kegiatan mengendarai kuda, dihubungkan dengan kegiatan militer yaitu korps pengendara kuda cavalry menduduki status lebih tinggi sebagai pasukan elit. Simbol dan tanda tentang pamor kekuatan tersebut mendapatkan tempat di era sekarang ini, seperti disampaikan Baudrillard (2004) bahwa konsumsilah yang menjadi inti ekonomi, bukan produksi. Konsumsi ini membuat orang-orang yang dalam hal ini adalah para bikers Kawasaki Ninja 250 cc yang tidak lagi sekedar mencari kebahagiaan, tidak berusaha mendapatkan sebuah kesetaraan/persamaan atau keseragaman, melainkan justru melakukan diferensiasi yang menjadi acuan dalam gaya hidup dan nilai, bukan kebutuhan ekonomi semata. Keinginan untuk menjadi berbeda memicu terjadinya kegiatan ekonomi yang berbasis pada konsumsi 'sign value', mereka mengenakan atribut-atribut sporty untuk lebih menonjolkan aspek kecepatan yang seolah-olah semangat dari si pembalap motor yang menjadi idola mereka tersebut ikut terserap dalam diri penggunanya, sehingga disini ada faktor Fetishisme, adanya semacam kekuatan supranatural yaitu keyakinan berlebihan yang menjadi simbol dalam penggunaan atribut tersebut. Secara ekstrim faktor fetishisme tersebut dapat memicu terjadinya istilah arogansi berkendara, seperti yang sering terlihat pada pengendara motor berkapasitas besar yang selalu menyisihkan pengendara lainnya dengan arogan dan bahkan masuk ke jalur cepat.

Seperti halnya penggunaan sepatu boot yang sudah mengalami perubahan konsumsi bukan dari segi kegunaan saja, tetapi lebih pada sebuah konsumsi makna dalam hubungannya dengan orang lain. Mereka lebih memilih untuk mengonsumsi tanda daripada melihat kegunaan objek itu sendiri. Masyarakat seperti ini disebut Baudrillard (2004) sebagai masyarakat konsumer. Ciri masyarakat konsumer menurut dia adalah ketika objek menandai status sosial hingga menggantikan kedudukan sosial yang berdasar pada ras, gender, dan kelas. Seseorang mendapatkan prestise dari konsumsi tanda yang dia lakukan terlepas dari ras, gender, dan kelasnya.

\section{KESIMPULAN}

Penggunaan sepatu boot oleh komunitas Kawasaki Ninja di Yogyakarta dapat ditinjau dari commodity fetishism yang dikemukakan oleh Marx yaitu bahwa komoditas memiliki dua aspek, yaitu: use value dan exchange value. Use value dari sepatu boot yang digunakan adalah adanya perlindungan kaki dari panas mesin yang ditunjang dengan desain potongan quarter yang menutupi betis, dan adanya mekanisme pelindung mata kaki dari resiko terkilir saat jatuh. Selain itu ada pelapis yang menunjang efektifitas dalam perpindahan gigi. Exchange value pada sepatu boot yang digunakan oleh komunitas Kawasaki Ninja di Yogyakarta lebih banyak dipengaruhi oleh kelangkaan material kulit yang pada akhirnya juga berdampak pada harga yang menjadi sangat mahal, sehingga mereka lebih memilih sepatu boot sport yang berbahan sintetis yang notabene lebih terjangkau.

Fetishisme pada sepatu boot juga dipengaruhi oleh symbolic value dan sign value yang diutarakan Baudrillard. Pengendara Kawasaki Ninja di Yogyakarta menggunakan sepatu boot, bukan sekedar pemenuhan aspek guna semata, tetapi saat ini sudah masuk dalam wilayah pemaknaan. Sepatu boot tidak lagi dilihat sebagai 
Anwar Hidayat, Desain Sepatu Boot Fetishisme Pada Bikers

kebutuhan antara subyek (user/pengguna) pada umumnya yaitu motor bebek dengan dengan obyek (sepatu boot), melainkan kapasitas yang lebih kecil. Saat itulah sepatu sudah berbicara antara subyek sebagai bikers boot model sport yang digunakan oleh dengan subyek-subyek lainnya dengan komunitas bikers Kawasaki Ninja di menyampaikannya melalui berbagai atribut Yogyakarta mewakili pemaknaan simbolis yang dikenakan terutama sepatu boot. akan status sosial yang lebih tinggi jika Terdapat strata sosial yang memisahkan dibanding para pengguna motor bebek atau antara kelompok motor besar yang bercitra motor buatan Jepang lainnya.

sport dan adventure dengan kelompok motor

\section{KEPUSTAKAAN}

Baudrillard, Jean. (1970), La Societe do Consommation atau Masyarakat Konsumsi, terjemahan Wahyunto. (2004), Kreasi Wacana, Yogyakarta.

Demello, Margo. (2009), Feet and Footwear: a Cultural Encyclopedia, ABC-CLIO LLC, California.

Marx, Karl (1867). Das Kapital I atau Kapital I : Proses Produksi Kapital, terjemahan Oey Hay Djoen (2004), Hasta Mitra, Jakarta.

Robinson, Andrew. (2009), In Theory - Karl Marx's Fetishisms, Routledge.

Steele, Valerie. (1998), Shoes: A Lexicon of Style, Scriptum Editions, UK.

Sutomo, Greg (2003), Kritik Seni Kritik Kesadaran, Penerbit Kanisius, Yogyakarta.

\section{Webtografi}

Asosiasi Industri Sepeda Motor (28 April 2013), Motorcycle Production

Wholesales Domestic and Exports.

http://www.aisi.or.id/statistic/

Ismoyo, Jessy (29 April 2013), Masyarakat Konsumsi Menurut Baudrillard.

http://ismoyojessy.blogspot.com/2011/11/masyarakat-konsumer-menurut-

baudrillard.html

Wikipedia (10 Juni 2013), Fetishism.

http://en.wikipedia.org/wiki/Fetishism 